\title{
Subacute Bacterial Endocarditis
}

National Cancer Institute

\section{Source}

National Cancer Institute. Subacute Bacterial Endocarditis. NCI Thesaurus. Code C34583.

Subacute inflammation of the endocardium. Streptococcus viridans is the usual etiologic agent of subacute bacterial endocarditis. The distinction between "acute" and "subacute" endocarditis has traditionally been made based on the pathogenic organism and clinical presentation. 